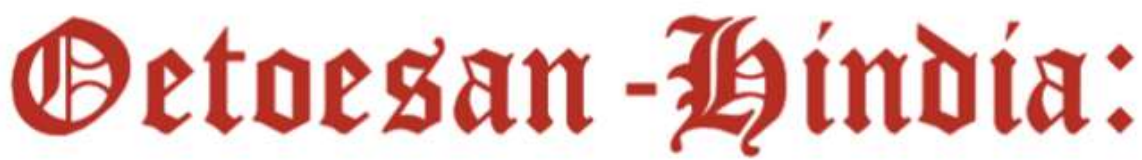 \\ Telaah Pemikiran Kebangsaan
}

Volume 1 No 2 Tahun 2019 Hlmn. 47-58

Artikel Masuk: 5 November 2019 | Artikel Diterima: 31 Desember 2019

\section{Mewujudkan keluarga sakinah melalui bimbingan pra-nikah}

\author{
Syifa Anita Fauzia
}

UIN Syarif Hidayatullah Jakarta, Jl. Ir. H. Djuanda No. 95, Ciputat, Tangerang Selatan, Indonesia, 15412

syifanita27@gmail.com

*surel korespondensi: syifanita27@gmail.com

\begin{abstract}
Abstrak
Pernikahan merupakan suatu ikatan pertalian antara seorang laki-laki dan seorang perempuan sebagai suami dan istri untuk membangun sebuah keluarga. Tujuan berkeluarga adalah untuk melestarikan keturunan dan membentuk keluarga sakinah hingga ke SurgaNya. Penelitian ini bertujuan untuk memberikan penerangan khususnya kepada pasangan calon suami istri bagaimana mewujudkan keluarga sakinah melalui bimbingan pra-nikah. Dengan mengikuti kursus atau bimbingan pranikah pasangan calon pengantin diberikan bekal ilmu pernikahan, keluarga, dan parenting sehingga lebih siap dalam menjalani hidup berumah tangga. Berdasarkan hasil penelitian, adanya bimbingan pra-nikah merupakan sebagai upaya preventif terjadinya Kekerasan Dalam Rumah Tangga (KDRT) yang berakibat pada keretakan pada rumah tangga atau perceraian.
\end{abstract}

Kata Kunci: Pernikahan; Bimbingan Pra-Nikah; Upaya Preventif

\begin{abstract}
Marriage is a bond between a man and a woman as husband and wife to build a family. The purpose of having a family is to preserve descent and form a family of sacraments to His heaven. This research aims to provide a special explanation to the spouse of prospective husband how to create a family sakinah through pre-marital guidance. By attending the course or guidance of pre-marital couples prospective brides are given the science of marriage, family, and parenting so that it is better prepared in living a married life. Based on the results of the research, there is a premarital guidance as an effort to prevent the occurrence of domestic violence (KDRT) resulting in a rift in the household or divorce.
\end{abstract}

Keywords: Marriage; Pre-marital Guidance; Preventive Work

Memasuki era revolusi industri 4.0 dan pengaruhnya dalam bingkai keluarga sangatlah besar. Sebagai contoh, jika dahulu orang tua mengasuh anaknya dengan tangan dan keringat sendiri maka di zaman sekarang orang 


\section{Mewujudkan keluarga sakinah Fauzia, S.A.}

tua lebih memilih mengasuh anak dengan menyewa jasa rumah tangga melalui berbagai aplikasi (Wildanshah, 2018). Jika dahulu orang tua dan anak akrab bermain bersama keluarga sembari menikmati suasana rumah, lain halnya era digitalisasi sekarang ini. Orang tua sibuk dengan gadget kesayangannya bercakap ria bersama followers di media sosial atau berselancar di online shop membeli barang yang diinginkannya. Anak-anak sibuk bermain permainan daring, menonton youtube, berselancar di interet kesana kemari sehingga mampu mengalihkan dunia yang seharusnya ia belajar dan memenuhi tugas dan kewajibannya sebagai seorang pelajar.

Pola asuh orang tua yang kurang baik terhadap anak akan berpengaruh terhadap perkembangan dan pertumbuhan serta kepribadian anak di masa yang akan datang. Ditambah lagi saat ini kita hidup dalam era dimana hampir semua aspek kehidupan manusia tergantikan oleh dunia virtualisasi yang semakin canggih dan mempermudah pekerjaan manusia. Hal inilah yang menyebabkan kehidupan berkeluarga era millenial dituntut untuk semakin cermat dalam membangun keluarga agar dapat mewujudkan keluarga sakinah mawaddah wa rahmah. Dalam buku yang diterbitkan Kementerian Agama (2013) menjelaskan dengan demikian pembekalan bagi pasangan calon pengantin menjadi wajib untuk dilakukan, termasuk diantaranya diberikan informasi seputar perundangan yang berlaku di Indonesia. Selain itu, diperlukannya pengarahan, bimbingan dan konseling oleh orang yang ahli dibidangnya, guna mencapai kebahagiaan lahir dan batin (Mubasyaroh, 2016: 2).

Adanya bimbingan pra-nikah dilatar belakangi oleh kejadian-kejadian tidak diinginkan dalam rumah tangga seperti perceraian dan Kekerasan Dalam Rumah Tangga (KDRT). Hal tersebut dapat terjadi karena kurangnya persiapan dan kematangan ilmu maupun mental sebelum membangun rumah tangga. Banyak sekali pasangan suami istri yang tidak memikirkan dan merencanakan segala sesuatu yang berkaitan dengan pernikahan dan kehidupan setelahnya. Selain itu, dalam membina sebuah rumah tangga, terkadang muncul persoalan-persoalan yang dapat menimbulkan konflik. Apabila konflik tersebut tidak dapat diselesaikan dengan ma'ruf, maka tidak sedikit pasangan yang berujung pada putusnya sebuah ikatan perkawinan (Hakim, 2016: 142).

Berdasarkan data dari Badan Peradilan Agama (Balidag) Mahkamah Agung, tingkat perceraian keluarga Indonesia dari waktu ke waktu semakin meningkat. Data perceraian tahun 2016 angka perceraian mencapai 19,9 persen dari 1,8 juta peristiwa. Sementara data 2017, angkanya mencapai 18,8 persen dari 1,9 juta peristiwa (Al-Asyhar, 2018). Penyebab pisahnya pasangan ini jika diurutkan tiga besar paling banyak terjadi akibat faktor ketidakharmonisan, yaitu sebanyak 91.841 perkara, tidak ada tanggungjawab 78.407 perkara, dan masalah ekonomi 67.891 perkara. Berdasarkan data Kementerian Agama RI yang disampaikan oleh Kepala Subdit Kepenghuluan, Anwar Saadi pada hari Jum'at (14/11/2014) 
menjelaskan bahwa perceraian yang terjadi dalam kurun waktu 2009 sampai tahun 2013 semakin hari semakin meningkat setiap tahunnya (Kompasiana, 2015; Republika, 2012). Hal tersebut dapat dilihat pada kejadian menikah dan cerai yang tertuang pada Gambar 1.

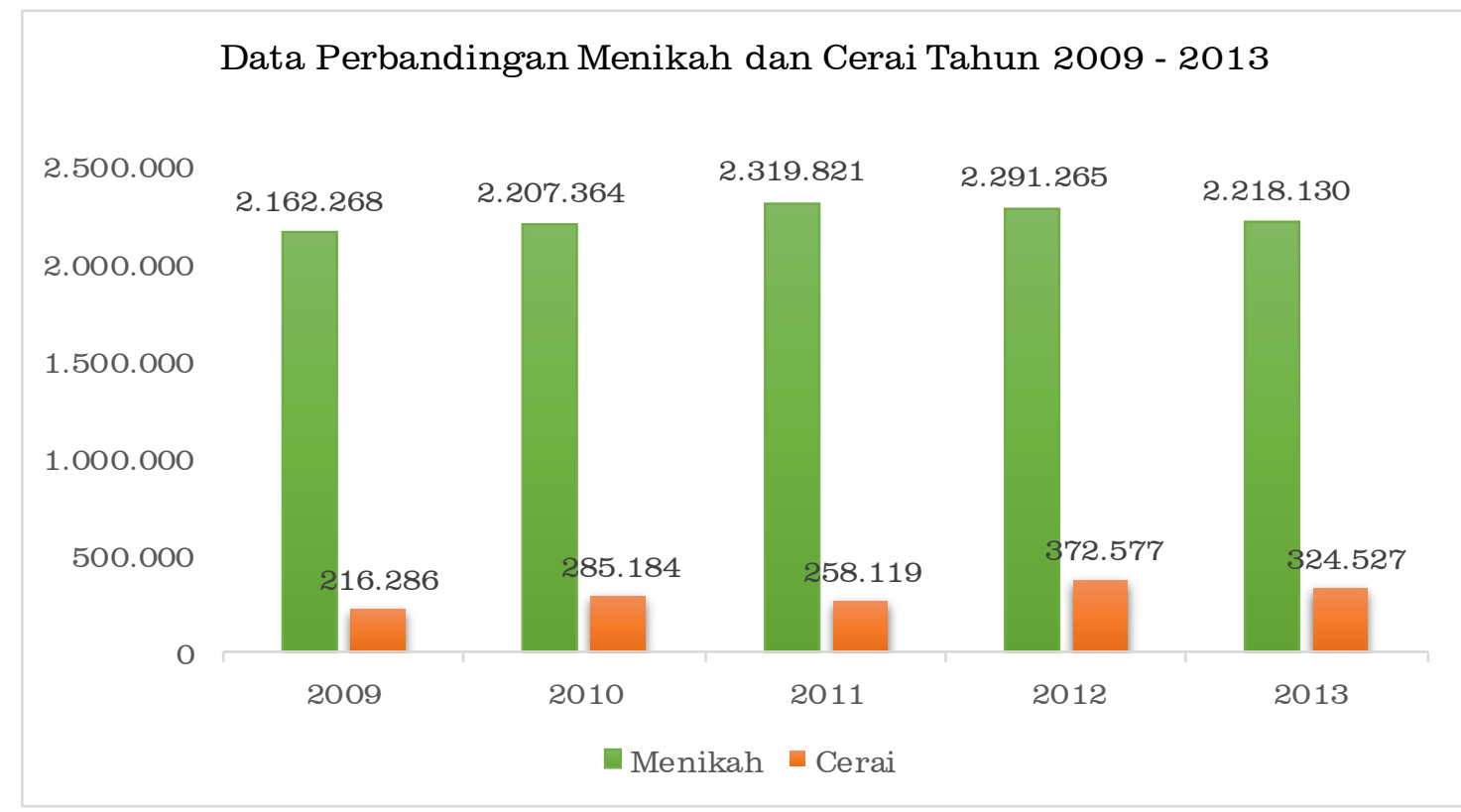

Gambar 1. Data Perbandingan Menikah dan Cerai Tahun 2009 - 2013

Sumber: Kompasiana, 2015; Republika, 2012

Komnas Perempuan Indonesia pada tahun 2017 menjelaskan bahwa Kasus Kekerasan Dalam Rumah Tangga (KDRT) di sisi lain mencapai 259.150 kasus kekerasan atas perempuan sepanjang tahun 2016, yang dihimpun dari data di Pengadilan Agama dan yang ditangani lembaga mitra pengadaan layanan di Indonesia. Data yang dihimpun 94 persen berasal dari kasus/perkara yang ditangani pengadilan agama yaitu 245.548 kasus kekerasan terhadap istri yang berakhir dengan perceraian (Lestari, 2017).

Menurut penelitian oleh Noor \& Agustitia (2018), bahwa dalam skala yang lebih kecil yaitu kota Surabaya, Pengadilan Agama kota Surabaya mencatat pada tahun 2016 terjadi 4.967 kasus perceraian. Adapun dua faktor terbanyak yang melatarbelakangi perceraian adalah faktor ketidakharmonisan sebanyak 1.378 kasus dan faktor ekonomi sebanyak 1.136 kasus. Secara umum, terjadi peningkatan kasus perceraian dari tahun ke tahun di Pengadilan Agama kota Surabaya.

Kurangnya kesadaran akan pentingnya bimbingan pra-nikah menjadi hal yang perlu diperhatikan khususnya bagi seorang penyuluh agama. Dalam sebuah penelitian menjelaskan bahwa banyaknya pernikahan yang hancur karena kurangnya persiapan, atau terkesan terburu-buru. Karena banyak sekali pasangan suami istri yang tidak memikirkan dan merencanakan halhal yang berkaitan tentang pernikahan dan kehidupan setelah itu. Atas dasar 
ketidaksadaran itu tidak sedikit suami istri kurang lihai dalam menghadapi dan menyelesaikan permasalahan rumah tangga sehingga tingkat perceraian di Indonesia semakin hari semakin meningkat setiap tahunnya (Hakim, 2016). Oleh karena itu, Penelitian ini bertujuan untuk memberikan penerangan khususnya kepada pasangan calon suami istri bagaimana mewujudkan keluarga sakinah melalui bimbingan pra-nikah.

\section{PEMIKIRAN}

Berangkat dari fenomena yang kerap penulis temui mengenai lingkungan sekitar yang kurang memperhatikan persiapan pernikahan terutama persiapan ilmu, mental atau psikis maupun persiapan kesehatan sebelum menikah (premartial check up). Dengan merujuk pada penelitian yang dilakukan oleh Hakim (2016), adanya kursus pra-nikah atau bimbingan pra-nikah dilatarbelakangi oleh faktor-faktor penyebab perceraian dan Kekerasan Dalam Rumah Tangga (KDRT). Menurutnya faktor utama penyebab terjadinya perceraian adalah ketidakpedulian suami dan istri atas tugas masing-masing, dan juga ketidaksiapan mereka membangun rumah tangga. Apabila seseorang kurang berpengetahuan dan kurang siap, maka tidak akan dapat mencapai tujuan yang diharapkan dalam pernikahan. Oleh karena itu, perlu adanya pelatihan-pelatihan tertentu sebelum dilaksanakan pernikahan untuk mengajarkan dan membekali para pasangan dalam menghadapi lika-liku kehidupan berumah tangga (Hakim, 2016: 142).

Dari hasil penelitiannya diketahui bahwa konsep kursus pra-nikah atau bimbingan pra-nikah sudah tercantum dalam Undang-Undang, Peraturan Presiden maupun Keputusan Menteri Agama. Adapun penyelenggara bimbingan pra-nikah sebagaimana tercantum dalam Peraturan Dirjen Masyarakat Islam Tahun 2013 pada Pasal 3 ayat (1) tentang Penyelenggaraan Kursus Pra-Nikah bahwa penyelenggara kursus pra-nikah adalah Badan Penasihat, Pembinaan, dan Pelestarian Perkawinan (BP4) atau lembaga/organisasi keagamaan Islam lainnya (Hakim, 2016: 144). Sedangkan secara garis besar materi yang disampaikan dalam bimbingan pra-nikah yaitu meliputi perkawinan, keluarga maupun parenting. Dengan mengikuti bimbingan pra-nikah harapannya para pasangan calon pengantin dapat bertambah pengetahuannya serta mengetahui tugas dan tanggung jawabnya sebagai seorang suami atau istri sehingga dapat mencapai tujuan pernikahan yaitu sakinah mawaddah wa rahmah.

Apa itu perkawinan? Nikah dalam Kamus Besar Bahasa Indonesia (KBBI) adalah: Ikatan (akad) perkawinan yang dilakukan sesuai dengan ketentuan hukum dan ajaran agama. Dalam Undang-Undang Nomor 1 Tahun 1974 tentang Perkawinan Pasal 1 menjelaskan bahwa perkawinan merupakan ikatan lahir bathin antara seorang laki-laki dan seorang perempuan sebagai suami isteri dengan tujuan membentuk keluarga (rumah tangga) yang 
bahagia dan kekal berdasarkan Ketuhanan Yang Maha Esa. Allah SWT berfirman dalam Al-Qur'an Surat Ar-Rum ayat 21 yang artinya,

"Dan di antara tanda-tanda kekuasaan-Nya ialah Dia menciptakan untukmu istri-istri dari jenismu sendiri, supaya kamu cenderung dan merasa tenteram kepadanya, dan dijadikan-Nya di antaramu rasa kasih dan sayang. Sesungguhnya pada yang demikian itu benar-benar terdapat tanda-tanda bagi kaum yang berpikir." (Q.S. Ar-Rum[30] : 21)

Menikah merupakan ibadah terlama dari sekian banyak ibadah yang kita lakukan. Menikah dalam pandangan Islam merupakan sunnah Rasulullah shalallahu 'alaihi wa sallam sebagaimana apabila shalat adalah wujud cinta kita kepada Allah dengan menunjukkan ibadah kepadaNya, maka nikah adalah wujud cinta kita kepada Nabi Muhammad shalallau 'alaihi wa sallam sebagai umatnya (Basyarahil, 2010: 274). Terkait hal tersebut Nabi shalallahu 'alaihi wa sallam bersabda,

"Barangisiapa yang tidak mengikuti sunnahku, ia bukan dari golonganku. Nikah adalah sunnahku. Barangsiapa cinta kepadaku, maka hendaklah berperilaku dengan sunnahku." (HR. Ahmad)

Menikah tidak hanya sekadar menyatukan dua hati menjadi satu ataupun dua insan saling mencinta, namun lebih daripada itu menikah juga terdapat peristiwa sosial (Mubasyaroh, 2016: 3), yaitu menyatukan dua keluarga yang berbeda latar belakang, kultur, budaya, adat istiadat, bahkan bahasa.

Penyuluh Pernikahan. Penyuluh agama hadir ditengah-tengah masyarakat untuk memberikan penerangan kepada masyarakat dari kegelapan menuju kepada terang benderang. Penyuluhan tidak lain merupakan bentuk pendidikan masyarakat untuk menunjang pembangunan masyarakat atau Community Development (Aminah, 2007: 64). Dalam Undang-Undang Nomor 16 Tahun 2006 tentang Sistem Penyuluhan Pertanian, Perikanan dan Kehutanan menjelaskan bahwa penyuluhan merupakan proses pembelajaran bagi pelaku utama serta pelaku usaha agar mereka mau dan mampu menolong dan mengorganisasikan dirinya dalam mengakses informasi, sebagi upaya untuk meningkatkan produktifitas, evisiensi usaha, pendapatan dan kesejahteraan serta meningkatkan kesadaran dalam pelestarian fungsi lingkungan hidup. Sebagai sebuah tindakan praktis, penyuluhan merupakan upaya-upaya yang dilakukan untuk mendorong terjadinya perubahan perilaku pada individu, kelompok, komunitas, ataupun masyarakat agar mereka tahu, mau, dan mampu menyelesaikan permasalahan yang dihadapi (Aminah, 2007).

Penyuluhan dikatakan sebagai penerangan, yaitu ibarat obor yang bertugas menerangi dan memberikan pencerahan bagi masyarakat dan 


\section{Mewujudkan keluarga sakinah Fauzia, S.A.}

lingkungan sekitar ditengah-tengah kegelapan. Hal tersebut dilakukan sebagai proses peningkatkan pengetahuan, keterampilan dan sikap masyarakat agar masyarakat tau, mau dan mampu mengubah sikap dan kehidupannya ke arah yang lebih baik. Sebagaimana dijelaskan Widiansyah (2007) yang menjelaskan, bimbingan dan penyuluhan Islam dalam proses penerangan diartikan sebagai proses untuk memberikan penerangan kepada masyarakat tentang segala sesuatu yang belum diketahui dengan jelas yang berkaitan dengan pemenuhan kebutuhan hidup masyarakat sehingga menjadi dipahami dan masyarakat memiliki kemauan dan motivasi untuk melaksanakan/menerapkan dalam rangka peningkatan kesejahteraan sosial masyarakat.

Bimbingan keluarga atau bimbingan pra-nikah membantu individu yang akan berkeluarga memahami tugas dan tanggung jawabnya sebagai anggota keluarga sehingga individu siap menghadapi kehidupan keluarga. Dalam pelaksanaannya bimbingan pra-nikah diselenggarakan oleh Kantor Urusan Agama (KUA) Kecamatan setempat atau lembaga lain yang mengurusi masalah pernikahan yaitu Badan Penasehat Pembinaan dan Pelestarian Perkawinan (BP4). BP4 merupakan lembaga yang disiapkan untuk membantu menjaga kelanggengan pernikahan (Noor \& Agustitia, 2016: 11). Dalam ketentuan Pasal 3 ayat (1) Peraturan Dirjen Masyarakat Islam Tahun 2013 tentang Penyelenggaraan Kursus Pra-nikah, penyelenggaraan kursus pranikah adalah Badan Penasehat, Pembinaan dan Pelestarian Perkawinan (BP4) atau lembaga/organisasi keagamaan Islam lainnya sebagai penyelenggara kursus pra-nikah yang telah mendapat Akreditasi dari Kementerian Agama. (Hakim, 2016 dalam Lampiran Peraturan Diketur Jenderal Bimbingan Masyarakat Islam Kementerian Agama Nomor DJ.II/542 Tahun 2013 tentang Pedoman Penyelenggaraan Kursus Pra-Nikah).

Dengan adanya ketentuan ini maka penyelanggaraan kursus pra-nikah dapat dilaksanakan oleh lembaga/badan di luar instansi pemerintah, dalam hal ini adalah KUA kecamatan, tetapi pelaksanaannya dilakukan oleh badan/lembaga swasta yang telah memenuhi ketentuan yang ditetapkan oleh pemerintah. Pemerintah dalam hal ini Kementerian Agama berfungsi sebagai regulator, pembina dan pengawas (Hakim, 2016: 144). Namun, seiring berkembangnya zaman tidak sedikit komunitas atau organisasi (di luar instansi pemerintahan) bergerak di bidang pernikahan dan parenting. Mereka memanfaatkan teknologi sebagai solusi untuk memberikan bimbingan pra-nikah melalui daring (online) atau melalui media sosial. Pelaksanaan bimbingan pra-nikah secara daring (online) cukup efektif dan efisien baik dari segi waktu maupun tempat, karena bisa dilakukan dimana saja dan kapan saja. Peserta bimbingan hanya perlu menyiapkan gawai atau telepon pintar (smartphone) dan menyiapkan diri untuk mendapatkan materi yang akan disampaikan oleh pemateri dalam jaringan (daring).

Adapun materi yang disampaikan dalam bimbingan pra-nikah, khususnya yang dilaksanakan di KUA tertera dalam Lampiran Peraturan 


\section{Oetoesan Hindia: Telaah Pemikiran Kebangsaan \\ Volume 1 No 2 Tahun 2019 Hlmn. 47-58}

Direktur Jenderal Bimbingan Masyarakat Islam Kementerian Agama Nomor DJ.II/542 Tahun 2013 tentang Pedoman Penyelenggaraan Kursus Pra-Nikah. Materi kursus pra-nikah tersiri dari kelompok dasar, kelompok inti dan kelompok penunjang. Kelompok dasar meliputi kebijakan Kementerian Agama tentang pembinaan keluarga sakinah, kebijakan Ditjen Bimas Islam tentang Pelaksanaan kursus pra-nikah, peraturan perundangan tentang perkawinan dan pembinaan keluarga, hukum munakahat, dan prosedur pernikahan. Kelompok inti meliputi pelaksanaan fungsi-fungsi keluarga, merawat cinta kasih dalam keluarga, manajeman konflik dalam keluarga. Sedangkan kelompok penunjang meliputi pendekatan andragogi, penyusun Satuan Acara Pembelajaran (SAP) dan micro teaching, pre-test dan penugasan atau rencana aksi (Hakim, 2016: 146-147).

Secara garis besar kursus atau bimbingan pra-nikah mengangkat materi yang berkenaan dengan keluarga dan rumah tangga yang akan dijalani setelah akad nikah diikrarkan, seperti mengelola keluangan keluarga, menajemen konflik keluarga, komunikasi yang efektif dalam keluarga, hingga materi parenting (pola asuh). Materi-materi yang disampaikan menjadi penunjang serta pencerah "keluarga seperti apa yang akan saya bangun?", "bagaimana seharusnya saya menghadapi dan menyelesaikan jika terjadi konflik dalam rumah tangga saya?", "pola asuh seperti apa yang akan saya gunakan dalam mendidik anak-anak saya?"

Selain mempersiapkan ilmu sebagai bekal dan hidup berumah tangga, mempersiapkan psikologis atau metal juga sangat dianjurkan bagi pasangan calon suami istri. Dalam persiapan psikologis pra-nikah aspek penting yang diangkat adalah sikap saling percaya, sikap saling menjaga perasaan pasangan, dan saling komunikasi (Noor dan Agustitia, 2016: 18). Aspek ini sangat penting untuk memberikan pemahaman kepada individu sebagai calon suami atau istri. Hal ini mengisyaratkan bahwa dalam pernikahan tidak lagi hanya mementingkan diri sendiri pribadi namun ada orang lain yang perlu lebih diperhatikan dan lebih dipentingkan dari diri sendiri yaitu pasangan kita (suami atau istri).

Untuk mempertahankan dan menjaga keharmonisan rumah tangga penting bagi setiap pasangan suami istri mengetahui dan memahami tugas dan kewajibannya masing-masing. Seandainya setiap pasangan suami-istri mengetahui batas-batas hak dan kewajibannya, niscaya mereka berdua akan hidup dengan bahagia dan sejahtera. (Al-Istanbuli, 2012: 334). Rabbani (2014) memaparkan ada beberapa kewajiban yang harus dilakukan oleh seorang istri yaitu (1) Meringankan mahar suami, (2) Mentaati suami, (3) Mengikuti tempat tinggal suami, (4) Meringankan beban belanja suami, (5) Berdandan hanya untuk suami, (6) Memelihara dan mengasuh anak, (7) Tidak keluar rumah kecuali dengan izin suami, (8) Menjaga harta suami, (9) Tidak berpuasa sunnah kecuali dengan izin suami, (10) Mensyukuri pemberian suami. Sebagaimana Allah swt. berfrman dalam Al-qur'an Surat Al-Baqarah ayat 228, yang artinya, 


\section{Mewujudkan keluarga sakinah Fauzia, S.A.}

"Para wanita (istri) mempunyai hak yang seimbang dengan kewajibannya menurut cara yang makruf. Akan tetapi, para suami mempunyai satu tingkatan kelebihan daripada istri." (Q.S. Al-Baqarah[2] : 228)

Kewajiban seorang istri dalam menaati perintah suaminya juga tertera jelas dalam sebuah hadits. Rasulullah shalallahu'alaihi wa sallam bersabda,

"Bila seorang wanita melaksanakan shalat lima waktu, berpuasa pada bulan suci Ramadhan, patuh pada suaminya dan menjaga kesuciannya, maka akan dikatakan padanya, 'Masukilah surga dari pintu yang manapun kamu suka." (HR. Ahmad dan ath-Thabrani dalam Majma az-Zawa'id 4/360)

Sedangkan kewajiban suami di dalam keluarga sudah ditentukan dalam ajaran agama Islam. Rabbani (2014) memaparkan beberapa kewajiban suami dalam keluarga, diantaranya adalah (1) Kewajiban memberi nafkah, (2) Kejujuran dalam berumah tangga, (3) Kewajiban suami bergaul dengan ma'ruf, (4) Kewajiban suami lemah lembut, (5) Kewajiban suami menumbuhkan suasana ibadah dalam rumah, (6) Membimbing istri degan syar'I, (7) Kewajiban suami saat istri sedang hamil, (8) Suami harus dapat berlaku adil. Suami merupakan kepala keluarga dalam rumah tangga, ia yang memimpin dan bertanggung jawab atas keluarganya. Suamilah sebagai nahkoda dalam perahu bernama rumah tangga yang mengarahkan, menuntun serta membimbing istri dan anak-anaknya sehingga mencapai tujuan keluarga dalam mewujudkan keluarga sakinah hingga sampai ke Surga terindahNya. Allah swt. berfirman dalam kalamNya dalam Surat AnNisaa' ayat 34 yang artinya,

"Kaum laki-laki itu adalah pemimpin bagi kaum wanita, oleh karena Allah telah melebihkan sebahagian mereka (laki-laki) atas sebahagian yang lain (wanita), dan karena mereka (lakilaki) telah menafkahkan sebagian dari harta mereka. Sebab itu maka wanita yang saleh, ialah yang taat kepada Allah lagi memelihara diri ketika suaminya tidak ada, oleh karena Allah telah memelihara (mereka). Wanita-wanita yang kamu khawatirkan nusyuznya, maka nasehatilah mereka dan pisahkanlah mereka di tempat tidur mereka, dan pukullah mereka. Kemudian jika mereka mentaatimu, maka janganlah kamu mencari-cari jalan untuk menyusahkannya. Sesungguhnya Allah Maha Tinggi lagi Maha Besar." (Q.S. AnNisaa[4] : 34)

Selain persiapan ilmu serta mental, persiapan atau tes kesehatan juga menjadi penting untuk disiapkan sebelum menikah. Tes kesehatan sebelum menikah bertujuan untuk mengetahui kondisi kesehatan dan kemungkinan 
penyakit yang diderita oleh pasangan dan potensi yang dapat menular atau tidak kepada pasangan meupun anak, sehingga bisa diantisipasi sedari dini. Menurut Al-Istanbuli (2012) bahwa saat ini, kebanyakan negara modern menetapkan peraturan wajib memeriksa kesehatan sebelum proses pernikahan dilangsungkan. Padahal dalam pandangan Islam proses tersebut lebih dahulu sudah dianjurkan sejak 14 abad yang lalu. Dalam petunjuk agama sudah dijelaskan bahwa bagi setiap calon pasangan adalah tidak diperkenankan menikah jika salah satu pasangannya mendertia penyakit menular.

Terkait urgensi persiapan kesehatan sebelum menikah, sebaiknya juga disinggung di dalam bimbingan pra-nikah maupun seminar-seminar pranikah yang dilaksanakan KUA maupun lembaga lain dengan layanan sejenis. Para calon pengantin dibekali materi-materi tentang beragam tes kesehatan yang harus dilakukan dan dipersiapkan. Misalnya, premartial check up yaitu pemeriksaan kesehatan sebelum menikah yang meliputi pemeriksaan fisik dan psikologis; vaksinasi guna mencegah penularan penyakit kepada pasangan dan calon anak; serta tes kesehatan lainnya.

Allah swt. telah memerintahkan kepada manusia untuk memiliki keturunan yang baik (tayyib), dan untuk memiliki keturunan yang baik berawal dari memilih pasangan yang baik pula. Sebagaimana do'a Nabi Zakariya a.s. kepada Allah swt. dalam Surat Ali-Imran (Tuasikal, 2019).

“Di sanalah Zakaria berdo'a kepada Tuhannya, Dia berkata, 'Ya Tuhanku, berilah aku keturunan yang baik dari sisi-Mu, sesungguhnya Engkau Maha Mendengar do'a." (Q.S. AliImran[3] : 38)

Maka dari itu untuk memilih pasangan yang baik Nabi shalallahu 'alaihi wa sallam telah bersabda: dari Ma'qil bin Yasaar radhiyallahu 'anhu, bahwasannya Rasulullah shalallahu 'alaihi wa sallam bersabda:

"Nikahilah wanita yang penyayang yang sabar punya banyak keturunan karena aku bangga dengan abnayaknya ummatku pada hari kiamat kelak." (HR. Abu Daud, no. 2050 dan AnNasai, no. 3229. Al-Hafidz Abu Thahir mengatakan bahwa hadits tersebut hasan)

Betapa sangat penting mempersiapkan segala sesuatu sebelum berumah tangga, baik persiapan secara fisik, mental, kesehatan, finansial maupun bekal ilmu yang cukup, sehingga akan tercapai kesadaran tentang hak dan tanggung jawab masing-masing sebagai pasangan suami istri yang bermuara pada pencapaian keluarga sakinah. Berdasarkan hasil penelitian Wulansari (2017) menunjukkan bahwa dampak bimbingan pranikah dalam memantapkan calon pengantin untuk mewujudkan keluarga sakinah yakni adanya persiapan dari calon pengantin terutama segi fisik terkait dengan materi yang disampaikan, pasangan calon pengantin sebelum mengikuti 


\section{Mewujudkan keluarga sakinah \\ Fauzia, S.A.}

bimbingan pranikah banyak hal yang tidak mereka ketahui. Namun, setelah mereka mengikuti bimbingan pra-nikah adanya kesadaran dari pasangan, akan hak dan tanggung jawab sebagai seorang suami dan istri. Sehingga dalam kehidupan rumah tangga terbentuk sikap saling pengertian, serta saling menghargai, karena dari kebanyakan kasus perceraian yang terjadi sekarang ini, salah satunya disebabkan oleh faktor kurangnya rasa pengertian antara suami istri dan komunikasi yang kurang efektif ataupun tidak adanya keterbukaan antara pasangan suami istri.

Mempersiapkan pernikahan tidak bisa dianggap sepele dari segi apapun. untuk memasuki gerbang kehidupan yang baru perlulah adanya persiapan atau bekal yang cukup, baik pengetahuan maupun yang lainnya. Perselisihan maupun perbedaan pendapat dalam rumah tangga pasti ada, namun dengan bekal pengetahuan yang cukup dapat meminimalisir perselisihan yang terjadi diantara suami dan istri. Selain itu dapat memberikan gambaran pola asuh yang seharusnya dilakukan dalam mendidik anak terutama di zaman serba canggih seperti sekarang ini. @tweetnikah (2014: 12) menyatakan, jika di sebuah kota yang anda tinggali tidak ada lembaga yang mengadakan (bimbingan pra-nikah), aktiflah mencari dan membaca buku tentang persiapan pernikahan termasuk aktif mengikuti seminar atau training tentang pernikahan.

Maka dapat dianalogikan, layaknya kita akan bepergian jauh pasti harus menyiapkan segala perbekalan dengan sebaik mungkin agar selama perjalanan tidak terjadi kendala yang berarti, kalaupun terjadi masalah maka sudah memiliki gambaran ataupun solusi yang tepat untuk menyelesaikan masalah tersebut. Sama halnya dengan pernikahan, menikah bukan hanya dilakukan sehari atau dua hari tetapi menikah untuk selama-lamannya. Maka dari itu wajib mempersiapkan diri sebaik mungkin baik dari pihak laki-laki maupun perempuan. Pastikan perbekalan yang dibawa cukup untuk mengarungi bahtera rumah tangga, agar dapat mewujudkan cita-cita bersama yaitu menjadi keluarga yang sakinah mawaddah wa rahmah yang selalu dilimpahkan keberkahan dan kebahagiaan oleh Allah SWT.

\section{SIMPULAN}

Menikah adalah ibadah dan ibadah terlama adalah pernikahan. Menikah bukan untuk bahagia, tetapi lebih daripada itu. Ada sebuah tugas dan tanggung jawab yang harus dilaksanakan baik oleh suami maupun istri dalam mengarungi bahtera rumah tangga. Bimbingan pra-nikah menjadi wadah dan sebagai upaya preventif untuk mempersiapkan calon suami dan istri dalam menghadapi segala problematika yang terjadi di dalam keluarga.

\section{DAFTAR RUJUKAN}

@tweetnikah. (2014). Aku, Kau \& KUA, Jakarta: PT Alex Media Komputindo. Al-Asyhar, T. (2018). Mencegah Badai Keluarga Indonesia. Retrieved December 10, 2019, from https://kemenag.go.id/berita/read/507618 
Al-Istanbuli, M. M. (2012). Kado Perkawinan. Jakarta: Pustaka Azzam.

Aminah, S. (2007). Makna Penyuluhan dan Transformasi Perilaku Manusia. Jurnal Penyuuhan, 4(1).

Anonim. (2012). Angka Perceraian Pasangan Indonesia Naik Drastis 70 Persen. Retrieved July 8, 2019, from https://www.republika.co.id/berita/nasional/umum/12/01/24/lya2yg-angkaperceraian-pasangan-indonesia-naik-drastis-70-persen

Anonim. (2015). Di Indonesia, 40 Perceraian Setiap Jam!. Retrieved July 7, 2019 , from https://www.kompasiana.com/pakcah/54f357c07455137a2b6c7115/diindonesia-40-perceraian-setiap-jam

Badan Litbang dan Diklat Kementerian Agama RI. (2013). Menelusuri Makna di Balik Fenomena Perkawinan di Bawah Umur dan Perkawinan Tidak Tercatat. Jakarta: Puslitbang Kehidupan Keagamaan Badan Litbang dan Diklat Kementerian Agama RI.

Basyarahil, A. A. S. (2010). Anakku Inilah Nasihatku: Shalat \& Pernikahan. Jakarta: Gema Insani.

Hakim, M. L. (2016). Kursus Pra-Nikah: Konsep Dan Implementasinya (Studi Komparatif Antara BP4 KUA Kecamatan Pontianak Timur Dengan GKKB Jemaat Pontianak). Jurnal Al-'Adalah. 13(2).

Lestari, S. (2017). KDRT Tertinggi Dalam Kekerasan Atas Perempuan di Indonesia. Retrieved October 20, 2019, from https://www.bbc.com/indonesia/indonesia-39180341

Mubasyaroh. (2016). Konseling Pra Nikah dalam Mewujudkan Keluarga Bahagia: Studi Pendekatan Humanistik Carl R. Rogers. Jurnal Bimbingan Konseling Islam. 7(2).

Noor, T. R. \& Agustitia, W. (2018). Pendampingan Persiapan Psikologis Pranikah pada Calon Pasangan Pengantin Muslim melalui Kursus Calon Pengantin (Suscatin) Berbasis Komunitas di Kelurahan Jambangan Kota Surabaya. Jurnal Pengabdian Kepada Masyarakat. 2(1).

Rabbani, M. A. (2014). 1001 Kewajiban Istri dalam Mengarungi Bahtera Rumah Tangga. Tangerang: Lembar Pustaka Indonesia.

Widiansyah, W. (2007). Urgensi Bimbingan dan Penyuluhan (Islam) Dalam Pembangunan Kesejahteraan Sosial. Komunika, 1(2).

Wildanshah. (2018). Potret Keluarga Muda Era Industri 4.0. Retrieved October 3, 2019, from https:/www.medcom.id/oase/kolom/nbwq78jKpotret-keluarga-muda-era-industri-4-O 
Mewujudkan keluarga sakinah Fauzia, S.A. 